\title{
DO POST-FIRE MULCHING TREATMENTS AFFECT REgENERATION IN SEROTINOUS LODGEPOLE PINE?
}

\author{
Micah Wright* and Monique Rocca \\ Department of Ecosystem Science and Sustainability, Colorado State University, \\ Fort Collins, Colorado 80523-1476, USA \\ *Corresponding author: Tel.: +1-970-408-0038; e-mail: wrightmicahc@gmail.com
}

\begin{abstract}
Broadcast mulching is a widely implemented post-fire erosion control method, although it remains uncertain how it affects post-fire regeneration in serotinous conifers. We used field data and unbiased conditional inference trees with random effects to test if mulching affects lodgepole pine (Pinus contorta Dougl. ex Loud. var. latifolia Engelm. ex S. Watson) regeneration following a wildfire in northern Colorado, USA. Our results suggest that post-fire application of straw mulch may have modest beneficial effects for regenerating lodgepole pine. However, these effects were minor compared to other spatial predictors of seedling density, including whether or not tree crowns were consumed in the fire and the presence of post-fire needle cast. These results suggest that post-fire mulching treatments in lodgepole pine ecosystems will have minimal effect on tree regeneration, and that managers need not be concerned about hindering regeneration when considering whether to use straw mulch for post-fire erosion mitigation in this forest type.
\end{abstract}

RESUMEN
El desparramado de mulching es un método ampliamente implementado para controlar la erosión post-fuego, a pesar de que es incierto el cómo afecta la regeneración en coníferas serotinas luego de un incendio. Usando datos de campo e inferencias sobre árboles testigo no sesgados con efectos aleatorios, determinamos si el mulching afecta la regeneración del pino contorta (Pinus contorta Dougl. ex Loud. var. latifolia Engelm. ex S. Watson), después de un fuego natural en el norte de Colorado, EEUU. Nuestros resultados sugieren que la aplicación de mulch post-fuego puede tener efectos benéficos modestos para la regeneración de pino contorta. Sin embargo, estos efectos fueron menores comparados con otros predictores espaciales de densidad de plantines, incluyendo el hecho de que las copas de los árboles hayan sido consumidas o no durante el fuego, y por la presencia de acículas secas post-fuego. Estos resultados sugieren que los tratamientos post-fuego en ecosistemas de pino contorta tendrán un efecto mínimo en la regeneración, y que los gestores no necesitan preocuparse por la regeneración que podría perturbar la posibilidad de utilizar paja como mulch para mitigar la erosión post-fuego en este tipo forestal. 
Keywords: Colorado, conditional inference trees, erosion control, lodgepole pine, mulching, $\mathrm{Pi}$ nus contorta, post-fire regeneration, USA

Citation: Wright, M., and M. Rocca. 2017. Do post-fire mulching treatments affect regeneration in serotinous lodgepole pine? Fire Ecology 13(3): 139-145. doi: 10.4996/fireecology.130306268

\section{INTRODUCTION}

Dry mulches are commonly applied following wildfire to mitigate post-fire erosion (Robichaud et al. 2010) until recovery of local vegetation stabilizes soils (Kruse et al. 2004). Moisture retained by mulch may be beneficial to regenerating vegetation in water-stressed areas (Fernandez et al. 2016), whereas deep mulch applications may inhibit vegetation establishment by creating physical barriers for germination or emergence (Cirelli et al. 2016) or by reducing the availability of key resources such as light and nitrogen (Kruse et al. 2004). However, whether straw mulch hinders the post-fire regeneration of serotinous conifer species such as Rocky Mountain lodgepole pine (Pinus contorta Dougl. ex Loud. var. latifolia Engelm. ex S. Watson) remains unclear. Serotinous lodgepole pine trees release stored seed en masse from the canopy soon after a fire event (Lotan and Critchfield 1990). Thus, seedlings may have the opportunity to establish prior to the application of mulch, allowing them to avoid the negative effects of mulching treatments more easily than do seedlings of other conifer species.

In this study, we investigated how postfire mulching treatments influenced the regeneration success of lodgepole pine following a 2012 wildfire in Colorado, USA. We used field data collected two years after the fire to examine whether or not straw mulch, which was applied within one year of the fire event, affected the abundance of lodgepole pine seedlings.

\section{METHODS}

\section{Study Area}

The High Park Fire was located in Larimer County at the northern end of the Front Range, Colorado (Figure 1). The fire was ignited by lightning on 9 June 2012 and burned more than 35000 hectares over the course of 22 days (NWCG 2012). The burned area included approximately 5000 hectares of mature lodgepole pine. Soil burn severity was high in much of the area that had been dominated by lodgepole pine, leading the Burned Area Emergency Response (BAER) team to recommend extensive aerial mulching treatments within severely burned areas, particularly those with steep slopes or where excessive erosion would threaten public health or safety (NWCG 2012). The initial treatments were completed during April 2013, less than one year after the fire event but prior to the two-

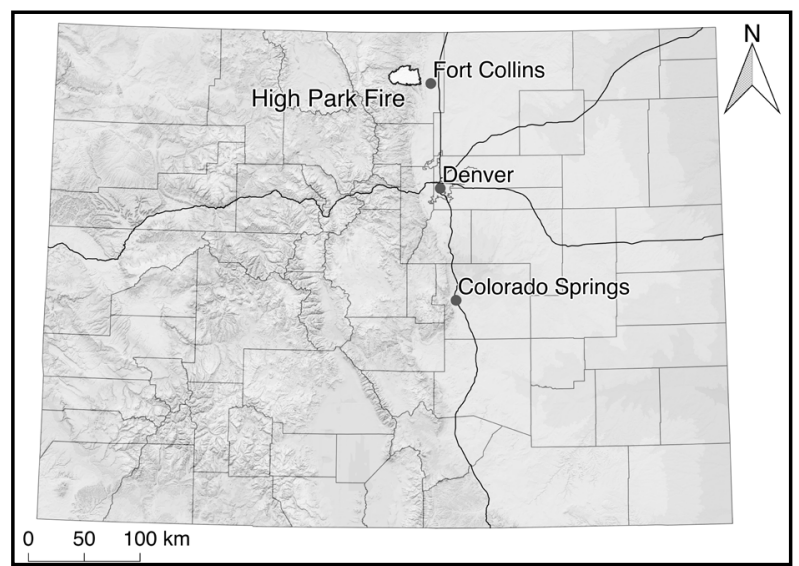

Figure 1. Map of Colorado, USA, showing the location and extent of the High Park Fire. The burned area is the area in white to the west of Fort Collins. Fire perimeter data created by Stone (2015). 
year seedling germination pulse that has been observed in lodgepole pine ecosystems (Turner et al. 1999). Most of the treatments utilized straw mulch. While some of the fire area was mulched with wood, small sample sizes prevented us from considering wood mulch.

\section{Data Collection}

Twelve field sites were sampled between June and August 2014 as part of a larger study on the combined effects of mountain pine beetle (MPB; Dendroctonus ponderosae Hopkins) mortality and fire on lodgepole pine regeneration. We located the study sites randomly, stratifying for MPB mortality and crown consumption based on $25 \mathrm{~m}$ resolution raster layers created by Stone (2015). During the stratification, we elected to combine the low and moderate burn severity classifications because moderate severity areas occupied narrow transition zones surrounding high severity patches, and both low (minimal needle scorch) and moderate (needles mostly scorched) severity represented the effects of surface fire (Stone 2015). We did not stratify field sites based on the presence of mulch; instead, we recorded mulch cover as we encountered it within the field sites. At each field site, we systematically placed a $25 \mathrm{~cm} \times 25 \mathrm{~cm}$ quadrat every $10 \mathrm{~m}$ within a $70 \mathrm{~m} \times 70 \mathrm{~m}$ (approximately 0.5 hectare) grid, for a total of 64 quadrat locations per site (with the exception of the first site, which was $100 \mathrm{~m} \times 100 \mathrm{~m})$. In each quadrat, we recorded lodgepole pine seedling abundance, and visually estimated cover percentage of the following variables: mulch, litter, total vegetation, and growable area. Litter cover consisted largely of post-fire needlecast, as there was little unburned litter in the study area. Growable area is the inverse of rock + coarse wood cover (i.e., the portion of the quadrat in which a seedling could conceivably establish).

We included other covariates known to explain the distribution of post-fire lodgepole pine seedlings (Wright 2016). To estimate the potential seed source surrounding each quadrat, we used a wedge prism to record the basal area of lodgepole pine that bore cones. We also field-verified our crown consumption variable using the wedge prism to create a binary variable classifying whether the tree crowns at each quadrat location had been consumed. If fewer than $50 \%$ of the trees tallied with the basal area prism retained needles at the time of sampling, that quadrat site was classified as high crown consumption. Otherwise, quadrat sites were classified as low crown consumption. Typically, tree crowns were either fully consumed or intact due to the stratified sampling design, which located sites in areas of more or less uniformly high or low crown consumption. We relied on the remotely sensed pre-fire MPB layer created by Stone (2015) to classify MPB mortality as "high" in a site if greater than $50 \%$ of the pixels within that site were classified as MPB mortality; otherwise it was classified as "low." Most sites had close to $0 \%$ or $100 \%$ MPB mortality - again because our original site stratification selected areas with a uniform MPB mortality classification. We recorded the quadrat slope by placing an inclinometer along the quadrat frame. We calculated site-level elevation by averaging elevation data extracted from a $25 \mathrm{~m}$ digital elevation model (Stone 2015).

\section{Analysis}

We restricted our analysis to field sites in which at least one quadrat had been treated with straw mulch. Additionally, quadrats with growable area of less than $10 \%$ were excluded from the analysis, leaving a total of 783 quadrats distributed over 12 sites. We used unbiased conditional inference trees with random effects (unbiased RE-EM trees; Fu and Simonoff 2015) to examine the drivers of lodgepole pine seedling abundance. Unbiased REEM tree algorithms improve upon previously available models by incorporating conditional 
inference for recursive partitioning, which is less prone to bias than other recursive partitioning algorithms such as CART (classification and regression trees; Breiman et al. 1984), assumes no underlying distribution in the data, and does not require pruning to avoid over-fitting (Hothorn et al. 2006).. Additionally, unbiased RE-EM trees also incorporate random effects, which allows for the analysis of grouped data (Sela and Simonoff 2012, Fu and Simonoff 2015). We specified site as the random effect; all other variables were treated as fixed effects. All statistical analyses were performed in R (R Core Team 2015) using a function for unbiased RE-EM trees developed by Fu and Simonoff (2015).

\section{RESULTS}

Our model suggested that post-fire litter cover had the most discriminating power for seedling abundance. The highest seedling counts (averaging 6 seedlings per quadrat, Figure 2) were found in quadrats that had abundant post-fire litter and elevations below $2648 \mathrm{~m}$.

The lowest seedling counts were predicted to occur in quadrats in which tree crowns had been consumed and potential seed source was limited (averaging $<1$ seedling per quadrat). Where the tree crowns were not consumed, mulch cover was the discriminating variable, resulting in the second highest average seedling abundance predicted by the model $(<3$ seedlings per quadrat). The model explained approximately $30 \%$ of the variation in lodgepole pine regeneration $\left(\mathrm{r}^{2}=0.301\right)$. No other variables were selected by the model.

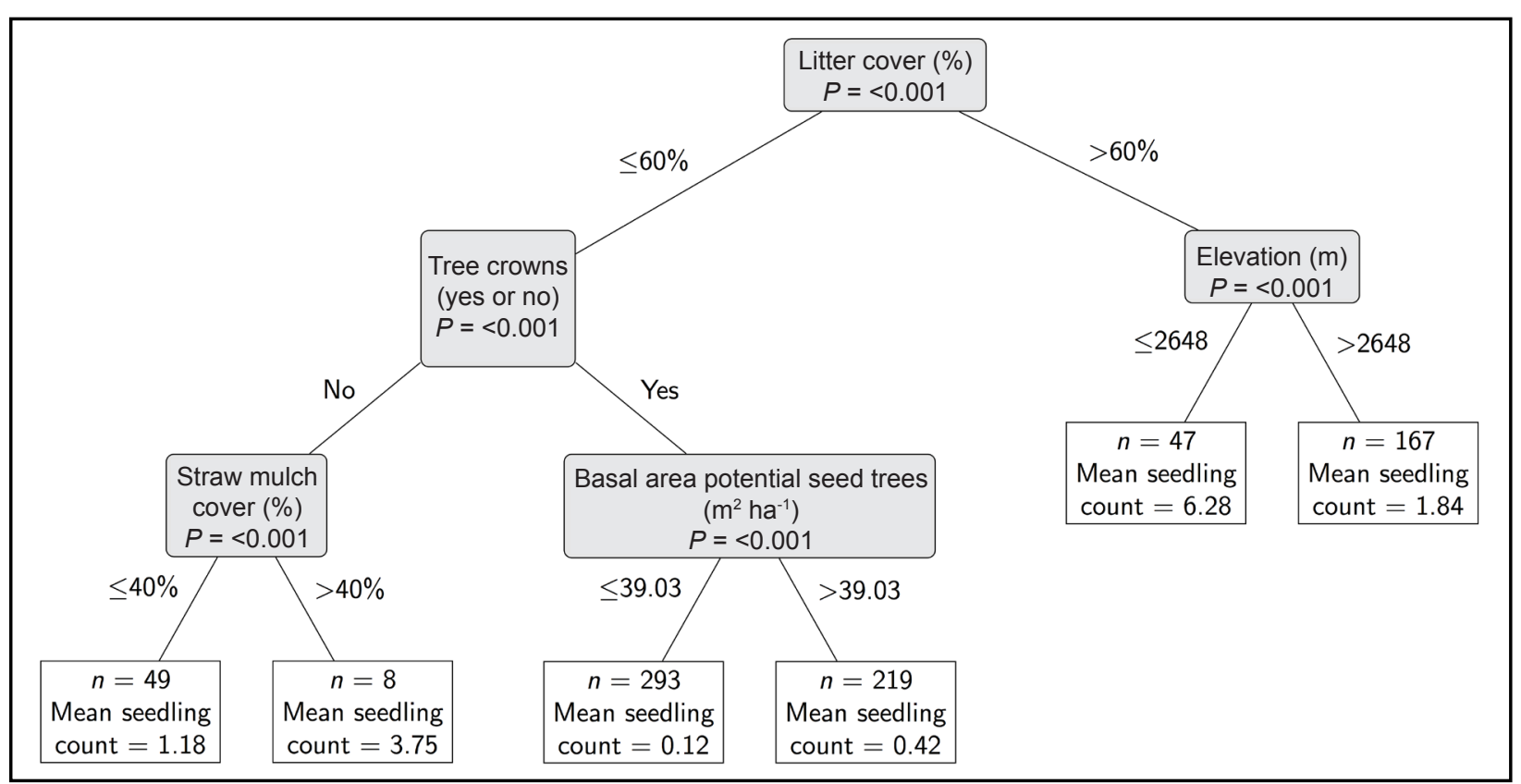

Figure 2. Plot of unbiased RE-EM tree. Each inner node (gray boxes) represents the partitioning variable, while the values for each partition are shown on the edges (lines) between the nodes. $P$-values in the inner nodes refer to tests of independence between the predictor and response. Mean predicted seedling abundance (mean seedling count) and sample size $(n)$ are given in the terminal nodes (white boxes). Straw mulch had a modest benefit for lodgepole pine regeneration, but only when tree crowns were not consumed. 
conditions that are already known to be favorable for lodgepole pine establishment - namely, when burning conditions are sufficient to release, but not destroy, the seed in the canopy seed bank (Anderson and Romme 1991, Turner et al. 1999, Schoennagel et al. 2003, Harvey et al. 2014). The positive relationship that we observed between straw mulch cover and lodgepole pine seedling abundance may be a result of increased soil moisture and lower soil temperatures typically associated with mulch applications (Amaranthus et al. 1993, Dodson and Peterson 2010, Santana et al. 2014). These mechanisms may also be at play in the strong relationship between post-fire litter and seedling abundance. However, areas with more post-fire litter also had more needles remaining in the crowns of surrounding trees, making it difficult to separate this effect from the overriding influence of fire in the canopy. While the mechanism behind the effects of elevation on seedling abundance in these high-litter areas remains uncertain, high-litter quadrats at elevations less than $2648 \mathrm{~m}$ had more cone-bearing trees on average than similar quadrats above $2648 \mathrm{~m}$ (data not shown), suggesting that differences in elevation may have been confounded by differences in the potential seed source.

The relationship between mulch and postfire lodgepole pine regeneration is likely influenced by additional factors that we were not able to measure. Mulching treatments may introduce non-native species (Kruse et al. 2004, Robichaud et al. 2010), which have been shown to compete with and inhibit the growth of native species (Harrod and Reichard 2000). While we did not separate native and introduced species, we did not detect any influence of competing vegetation as a whole. It is possible that mulch limited the establishment of competing vegetation at our sites (Amaranthus et al. 1993). Mulch may also be beneficial to post-fire regeneration by moderating any detrimental effects of erosion, especially during extreme runoff events. Indeed, field observations suggested that seedling abundance varied with apparent erosion and deposition of mineral soil.

Overall, these results suggest that post-fire mulching treatments do not negatively influence the post-fire recovery process in this forest type, and may even enhance regeneration under moderate burning conditions.

\section{ACKNOWLEDGEMENTS}

We are thankful to our field assistants E.V. Wright and P. Engelstad for their work in data collection, and to W.H. Romme, M.A. Lefsky, C.M. Hoffman, C.C. Rhoades, and J.S. Sibold for their comments during data collection and analysis. Funding for this work was provided by the National Science Foundation (DIB-1339928).

\section{LITERATURE CITED}

Amaranthus, M.P., J.M. Trappe, and D.A. Perry. 1993. Soil moisture, native revegetation, and Pinus lambertiana seedling survival, growth, and mycorrhiza formation following wildfire and grass seeding. Restoration Ecology 1(3): 188-195. doi: 10.1111/j.1526-100X.1993. tb00024.x

Anderson, J.E., and W.H. Romme. 1991. Initial floristics in lodgepole pine (Pinus contorta) forests following the 1988 Yellowstone fires. International Journal of Wildland Fire 1(2): 119124. doi: 10.1071/WF9910119 
Breiman L., J.H. Friedman, R.A. Olshen, and C.J Stone. 1984. Classification and regression trees. Wadsworth International Group, Belmont, California, USA.

Cirelli, D., T. Vinge, and V.J. Lieffers. 2016. Assisted lodgepole pine regeneration on reclamation sites using logging slash as both a mulch and natural seed source. Canadian Journal of Forest Research 46(9): 1132-1137. doi: 10.1139/cjfr-2016-0157

Dodson, E.K., and D.W. Peterson. 2010. Mulching effects on vegetation recovery following high severity wildfire in north-central Washington State, USA. Forest Ecology and Management 260(10): 1816-1823. doi: 10.1016/j.foreco.2010.08.026

Fernandez, C., J.A. Vega, T. Fonturbel, A. Barreiro, A. Lombao, M.X. Gomez-Rey, M. Diaz-Ravina, and S. Gonzalez-Prieto. 2016. Effects of straw mulching on initial post-fire vegetation recovery. Ecological Engineering 95: 138-142. doi: 10.1016/j.ecoleng.2016.06.046

Fu, W., and J.S. Simonoff. 2015. Unbiased regression trees for longitudinal and clustered data. Computational Statistics and Data Analysis 88: 53-74. doi: 10.1016/j.csda.2015.02.004

Harrod, R.J., and S. Reichard. 2000. Fire and invasive species within the temperate and boreal coniferous forests of western North America. Pages 95-101 in: K.E.M. Galley and T.P. Wilson, editors. Proceedings of Fire Conference 2000: the first national congress on fire ecology, prevention, and management, on the invasive species workshop - the role of fire in the control and spread of invasive species. Miscellaneous Publication 11, Tall Timbers Research Station, Tallahassee, Florida, USA.

Harvey, B.J., D.C. Donato, and M.G. Turner. 2014. Recent mountain pine beetle outbreaks, wildfire severity, and postfire tree regeneration in the US northern Rockies. Proceedings of the National Academy of Sciences 111(42): 15120-15125. doi: 10.1073/pnas.1411346111

Hothorn, T., K. Hornik, and A. Zeileis. 2006. Unbiased recursive partitioning: a conditional inference framework. Journal of Computational and Graphical Statistics 15(3): 651-674. doi: 10.1198/106186006X133933

Kruse, R., E. Bend, and P. Bierzychudek. 2004. Native plant regeneration and introduction of non-natives following post-fire rehabilitation with straw mulch and barley seeding. Forest Ecology and Management 196(2-3): 299-310. doi: 10.1016/j.foreco.2004.03.022

Lotan, J.E., and W.B. Critchfield. 1990. Pinus contorta. Pages 302-315 in: R.M. Burns and B.H. Honkala, technical coordinators. Silvics of North America, Volume 1. Agriculture Handbook 654, USDA Forest Service, Washington, D.C., USA.

NWCG [National Wildfire Coordinating Group]. 2012. High Park Fire Burned Area Emergency Response (BAER) report. <https://inciweb.nwcg.gov/photos/COARF/2012-06-09-15:25high-park-fire/related_files/ftp-20120720-120024.pdf $>$. Accessed 3 November 2014.

R Core Team. 2015. R: a language and environment for statistical computing. R Foundation for Statistical Computing, Vienna, Austria. <http://www.r-project.org/>. Accessed 4 May 2015.

Robichaud, P.R., L.E. Ashmun, and B.D. Sims. 2010. Post-fire treatment effectiveness for hillslope stabilization. USDA Forest Service General Technical Report RMRS-GTR-240, Rocky Mountain Research Station, Fort Collins, Colorado, USA.

Santana, V.M., J.G. Alday, and M.J. Baeza. 2014. Mulch application as post-fire rehabilitation treatment does not affect vegetation recovery in ecosystems dominated by obligate seeders. Ecological Engineering 71: 80-86. doi: 10.1016/j.ecoleng.2014.07.037

Schoennagel, T., M.G. Turner, and W.H. Romme. 2003. The influence of fire interval and serotiny on postfire lodgepole pine density in Yellowstone National Park. Ecology 84(11): 2967-2978. doi: 10.1890/02-0277

Sela, R.J., and J.S. Simonoff. 2012. RE-EM trees: a data mining approach for longitudinal and clustered data. Machine Learning 86(2): 169-207. 
Stone, B. 2015. Mapping burn severity, pine beetle infestation, and their interaction at the High Park Fire. Thesis, Colorado State University, Fort Collins, USA.

Turner, M.G., W.H. Romme, and R.H. Gardner. 1999. Prefire heterogeneity, fire severity, and early postfire plant reestablishment in subalpine forests of Yellowstone National Park, Wyoming. International Journal of Wildland Fire 9(1): 21-36. doi: 10.1071/WF99003

Wright, M. 2016. Lodgepole pine regeneration after mountain pine beetle and wildfire: a case study in the High Park Fire, CO. Thesis, Colorado State University, Fort Collins, USA. 